\title{
Is Black Cohosh a Hepatotoxic Medicinal Herb?
}

\author{
Luigi Gori Fabio Firenzuoli \\ Center of Natural Medicine, S. Giuseppe Hospital, Empoli, Italy
}

Recently, the European Medicines Agency (EMEA) and the Committee on Herbal Medicinal Products (HMPC) have released a public statement to draw the attention of European health authorities to 42 cases ( 34 directly reported from European national competent authorities and 8 published) of suspected hepatotoxic reactions to Cimicifugae racemosae rhizoma (black cohosh, root) in patients, probably all of them women, who were treated for menopause-related disorders. Following a review of all data available, this statement assumes a connection between herbal medicinal products that contain Cimicifugae racemosae rhizoma and human hepatotoxic adverse reactions. Nevertheless, this highly authoritative review of such an impressive number of cases concludes in its summary that 'Overall, all discussed cases of literature and pharmacovigilance reports are poorly documented,' and only 'two can be considered as possible' and 'two can be classified as probable' $[1, \mathrm{p} 9]$ :

(1) In case 28, according to the numeration in the EMEA statement, RUCAM score 4, the only case directly collected from European national competent authorities, the adverse reaction was considered possible, but information on differential diagnostic assessment was not available. The patient consumed $80 \mathrm{mg}$ of an unknown extract daily and for an unknown period.

(2) In another case report [2] (RUCAM score 3) the patient was a 54-year-old woman suffering from hypothyroidism, fibromyalgia, osteoarthritis and depression. She had taken $1,000 \mathrm{mg}$ black cohosh (unclear, if a type of extract or crude drug) daily for several months. The patient was on fluoxetine, propoxyphene and paracetamol (a well known hepatotoxic substance) concomitantly and used to drink 2 glasses of wine in the evenings. The statement claims 'that since there is no further information on the herbal preparation, the case report is not of great relevance in the assessment of cimicifuga-related hepatotoxicity' [1].
(3) A 57-year-old multimorbid Afro-American woman [3] (RUCAM score 7) with a history of polymyositis had developed an autoimmune hepatitis about 3 weeks after the first intake of Cimicifugae racemosae rhizoma (brand and dose unknown; no information if it was a combination product). After discontinuation of Cimicifugae racemosae rhizoma intake and starting a therapy with steroids and azathioprine, the patient recovered. Here, autoimmune hepatitis may as well have been a manifestation of a multisystem autoimmune disease. According to the draft recommendations of the Scientific Advisory Panel Subgroups on Hepatotoxicity, the case could be classified as idiosyncratic liver necrosis. Inititally, the causal relationship to black cohosh in this case was assessed 'unclassifiable', as information concerning the reaction was considered incomplete and inconsistent, and the follow-up publication includes more (although to some extent still inconsistent) information about the therapy [1]).

(4) In another well-documented case [4] (RUCAM score 6) the dose administered was $500 \mathrm{mg} /$ day. The reaction was described as hepatocellular, other causes of acute hepatitis were excluded. The provisional clinical diagnosis was autoimmune hepatitis. Therapy started with $60 \mathrm{mg}$ prednisone / day for 5 weeks. Liver enzymes improved, but due to an aggravation of coagulopathy and encephalopathy, the patient underwent orthotopic liver transplantation. In the explanted organ, histological features of acute hepatitis, fibrous linkage of portal tracts and cholestasis were observed after 5 weeks on corticosteroids. Yet, in this case, too, the exact content of the remedy based on black cohosh is unclear, and it is not reported if it was an extract or crude drug, and if it contained other toxic substances, i.e. heavy metals. Later, Levitsky [4] reported that the patient neither drank, nor used drugs, nor took any other medication. However, in a US District Court proceeding the woman admitted that she regularly consumed alcohol, and used large doses of ibuprofen, a non-steroidal anti-inflamma-

\begin{tabular}{|c|c|c|}
\hline KARGER & (C) 2007 S. Karger GmbH, Freiburg & $\begin{array}{l}\text { Fabio Firenzuoli, MD } \\
\text { Center of Natural Medicine }\end{array}$ \\
\hline $\begin{array}{l}\text { Fax +49 } 7614520714 \\
\text { E-mail Information@Karger.de } \\
\text { www.karger.com }\end{array}$ & $\begin{array}{l}\text { Accessible online at: } \\
\text { www.karger.com/fok }\end{array}$ & $\begin{array}{l}\text { S. Giuseppe Hospsital } \\
\text { Via Paladini 1, 50053 Az USL } 11 \text { Empoli, Italy } \\
\text { Tel. +39 0571-702626, Fax -702639 } \\
\text { E-mail f.firenzuoli@usl11.toscana.it }\end{array}$ \\
\hline
\end{tabular}


tory drug, on a regular basis, and at the time of transplantation also took valaciclovir, and pseudoephedrine [5].

In our opinion it is very important to know the brand, the dose of substance consumed, the type of extract, the content of possible contaminants (wrong plants, pesticides, heavy metals, aflatoxins) [6] before making an official statement about any adverse reaction to a herb-based product. Also, any conclusion of a relationship between a certain herbal remedy and an adverse reaction, especially if liver-related, should follow the same rules that hold for conventional drugs [6] and refer to a single substance only. If the preparation investigated contains several substances, no clear connection can be established between adverse reactions and a single herb, unless it is a well known hepatotoxic substance, e.g. Teucrium chamaedrys, or it accounts for a very high proportion in the respective remedy. For the time being, the EMEA statement can, paradoxically, be regarded as the proof that the risk of black cohosh hepatoxicity is small: although every year millions of doses of black cohosh are used worldwide $(800,000$ packets every year sold only in Italy, FEDERSALUS data), no fully documented case of liver adverse reaction has been reported so far. To the contrary, safety of black cohosh can be regarded as sufficiently established by the fact that clinical trials in a total of more than 2,000 participants have not reported any hepatotoxic reactions [7]. In the past, potential toxicity of black cohosh was suspected because catechols from black cohosh are activated to quinoid metabolites; however, catechols are not absorbed by the bowel [7]. While an important safety issue is the interaction of black cohosh with synthetic drugs due to the interference with the metabolic pathway of cytochrome P4503A4 [8], this could also be the cause of important adverse reaction especially in multi-drug therapies.

\section{Referencees}

1 Assessment of case reports connected to herbal medicinal products containing cimicifugae racemose rhizoma (black cohosh, root). Doc. Ref.. EMEA/269259/2006. Available at: http://www. emea.eu.int/pdfs/human/hmpc/26925806en.pdf [accessed March 16, 2006].

2 Lynch CR, Folkers ME, Hutson WR: Fulminant hepatic failure associated with the use of black cohosh: A case report. Liver Transplant 2006;12: 989-992.
3 Cohen SM, O'Connor AM, Hart J, Merel NH, Te HS: Autoimmune hepatitis associated with the use of black cohosh: A case study. Menopause 2004;11: 575-577.

4 Levitsky J, Alli TA, Wisecarver J, Sorrell MF: Fulminant liver failure associated with the use of black cohosh. Dig Dis Sci 2005;50:538-539.

5 US District Court - Nebraska. Grant and Beck v. Pharmavite, LLC and Nutraceutical Corp. www. ahpa.org/Portals/0/pdfs/06_0908_BlackCohosh_NebraskaDistrictCt.pdf [accessed March 16, 2006]
6 Firenzuoli F, Gori L, Neri D: Clinical phytotherapy: Opportunities and problematics. Ann Ist Super Sanità 2005;41:27-33.

7 National Institutes of Health (ed): Workshop on the Safety of Black Cohosh in Clinical Studies, Bethesda, MD, November 22, 2004. http://nccam. nih.gov/news/pastmeetings/blackcohosh_mtngsumm.htm [accessed March 16, 2006].

8 Tsukamoto S, Aburatani M, Ohta T: Isolation of CYP3A4 Inhibitors from the Black Cohosh (Cimicifuga racemosa). eCAM 2005;2:223-226. 